Provided by the author(s) and University of Galway in accordance with publisher policies. Please cite the published version when available.

\begin{tabular}{|c|c|}
\hline Title & $\begin{array}{l}\text { Humanitarian encounters: Biafra, NGOs and imaginings of the } \\
\text { Third World in Britain and Ireland, 1967-70 }\end{array}$ \\
\hline Author(s) & O'Sullivan, Kevin \\
\hline $\begin{array}{l}\text { Publication } \\
\text { Date }\end{array}$ & 2014-08-21 \\
\hline $\begin{array}{l}\text { Publication } \\
\text { Information }\end{array}$ & $\begin{array}{l}\text { O'Sullivan, Kevin. (2014). Humanitarian encounters: Biafra, } \\
\text { NGOs and imaginings of the Third World in Britain and } \\
\text { Ireland, 1967-70. Journal of Genocide Research, 16(2-3), 299- } \\
\text { 315. doi: } 10.1080 / 14623528.2014 .936706\end{array}$ \\
\hline Publisher & Taylor \& Francis \\
\hline $\begin{array}{l}\text { Link to } \\
\text { publisher's } \\
\text { version }\end{array}$ & http://dx.doi.org/10.1080/14623528.2014.936706 \\
\hline Item record & http://hdl.handle.net/10379/6616 \\
\hline DOI & http://dx.doi.org/10.1080/14623528.2014.936706 \\
\hline
\end{tabular}

Downloaded 2023-04-26T12:00:17Z

Some rights reserved. For more information, please see the item record link above. 


\title{
Humanitarian encounters: Biafra, NGOs and imaginings of the Third World in Britain and Ireland, 1967-70
}

\author{
Kevin O'Sullivan \\ National University of Ireland Galway \\ in: Journal of Genocide Research, 16:2-3 (2014), pp. 299-315. \\ - doi: http://dx.doi.org/10.1080/14623528.2014.936706
}

\begin{abstract}
This article examines the influence of the Biafran humanitarian crisis on British and Irish conceptions of the Third World. Drawing on evidence from NGOs in both countries, it argues that the explosion of non-governmental activity in this period, combined with the unprecedented attention afforded to the relief effort, crystallized a popular vision of the Third World that was rooted in Western internationalism and the legacies of the imperial world. The model of humanitarian action pursued by Oxfam, Save the Children, Africa Concern, and others, transformed non-governmental actors into key mediators between the West and the Third World. Yet, this article argues, the image they presented, and the tactics they pursued, can only be understood as part of a broader adjustment to a decolonized world. From very different beginnings (British postcolonial responsibilities versus a strong anticolonial narrative in Ireland) considerable similarities emerged between British and Irish NGOs. The response to Biafra was an extension of the missionary and colonial service ethos, and generated a model of relief that privileged humanitarian action over local political and human agency. That paternalistic approach further reinforced traditional attitudes to the Third World through renewed emphases on donation, dependency, expatriate volunteers, and Western concepts of 'needs' and 'development'. This article concludes, therefore, by arguing that Biafra played a vital role in the shift from imperial humanitarianism to neohumanitarianism and the rise of liberal humanitarian governance. The vision of an inclusive 'common humanity' the NGOs espoused was in practice rooted in a very Western understanding of humanitarian responsibilities and a very Western image of the Third World.
\end{abstract}

\section{Introduction}

The Biafran humanitarian crisis holds a critical place in the history of NGOs. It prompted the creation of new agencies, like Africa Concern, and thrust existing ones, like Oxfam, into a spotlight they have left only rarely since. As part of a wider 'NGO moment', it focussed public and official attention on the role of non-state actors and accelerated the emergence of an internationalized, professionalized aid industry that took centre stage in the mid 1980s. The relief operation also remains critical to understanding the mechanics of nongovernmental aid. Biafra was both 'totem and taboo' for NGOs: it not only drew attention to their actions, but also exposed their inexperience, bordering at times on naivety, in dealing with the politics of intervention and the use of hunger as a weapon of war. ${ }^{1}$

Yet if we turn the lens inwards, as this article does, the story of NGO involvement in the Nigerian civil war also sheds considerable light on European attitudes to the Third World in the postcolonial era. From the late 1960s NGOs emerged as 'symbols of societal responsibility and global morality' and important filters in the West's relationship with the global South. ${ }^{2}$ The kind of 'people-to-people' action they espoused adapted traditional

\footnotetext{
${ }^{1}$ Alex de Waal, Famine crimes: politics and the disaster relief industry in Africa (Oxford: James Currey, 1997), pp. $72-73$.

${ }^{2}$ Terje Tvedt, Angels of mercy or development diplomats? NGOs and foreign aid (Oxford: James Currey, 1998), p. 2.
} 
notions of charity and philanthropy for a global era. Biafra played a critical role in that process. Not only did it transform the reputation of non-state actors, it also generated a particular understanding of the postcolonial world and with it a particular role for humanitarian aid. The result owed less to the inclusive, global humanitarianism suggested by NGO rhetoric and more to Western internationalism and a very Western imagining of the Third World.

To articulate that argument, this article draws on case studies from Britain (Christian Aid, Oxfam, and the Save the Children Fund) and Ireland (Africa Concern, Gorta, and Christian missionary societies), along with wider lessons from the Western humanitarian sector. Both countries featured prominently in the Biafran relief effort and shaped their approach to humanitarianism within a strongly Anglophone tradition, but their attitudes were marked by contrasting approaches to empire and its legacies. They had different vested interests in Nigeria: for Britain postcolonial responsibilities were paramount, for Ireland the needs of the 'spiritual empire' dominated. ${ }^{3}$ Biafra also played a contrasting role in shaping national identities in the postcolonial era: expressed in the shift from the 'civilising' goal of imperialism to the 'saving' aims of humanitarianism in Britain, and in the rhetoric of common experience (of famine, anticolonialism, and Catholicism) in Ireland. ${ }^{4}$ Yet the significance of these case studies lies not in their contrasting backgrounds. Rather it is to be found in the striking similarities that emerged in British and Irish popular reactions to Biafra: in the values they imbued in NGOs, and in the image of the Third World they created.

This article describes that response in terms of four themes. It looks firstly at Biafra's impact in bringing NGOs to centre stage as mediators between Britain, Ireland and the Third World. That newfound standing gave those organizations considerable influence. But it also led to questions, not least the one posed by the second section of this article: to what extent were NGOs products of their circumstances - namely, a decolonized world? That leads us to our third theme: paternalism, and the extent to which traditional attitudes to Africa were reinforced in renewed emphases on donation, dependency, and Western concepts of 'need' and 'development'. It also says much about the concluding theme of this article: the ideal of a 'common humanity' that was a constant reference point in NGO rhetoric. The response to Biafra unfolded in a Europe embroiled in the social, political, cultural and emotional transition from imperial to postcolonial worlds. It created a humanitarianism that was complex and at times paradoxical. And in its emphasis on disaster, famine and the importance of the expatriate volunteer, it cemented a vision of the Third World that decades of development education programmes have found difficult to resolve.

\section{Biafra, the 'NGO moment' and the birth of the modern humanitarian industry}

\footnotetext{
${ }^{3}$ For an introduction to that concept, see Fiona Bateman, 'Ireland's spiritual empire: territory and landscape in Irish Catholic missionary discourse', in Hilary M. Carey (ed.), Empires of religion (London: Palgrave Macmillan, 2008), pp. 267-287. There have been a number of publications in recent years that deal with Irish involvement in the Biafran crisis; see, for example, Fiona Bateman, 'Ireland and the Nigeria-Biafra war: local connections to a distant conflict', New Hibernia Review, Vol. 16, No. 1, 2012, pp. 48-67; Fiona Bateman, 'Ireland and Biafra', in Chima J. Korieh (ed.), The Nigeria-Biafra war (Amherst, NY: Cambria Press, 2012), pp. 111-136; Enda Staunton, 'The case of Biafra: Ireland and the Nigerian civil war', Irish Historical Studies, Vol. 31, No. 124, 1999, pp. 513-534; Kevin O'Sullivan, Ireland, Africa and the end of empire: small state identity in the Cold War, 1955-75 (Manchester: Manchester University Press, 2012), pp. 83-131; and Ken Waters, 'Influencing the message: the role of Catholic missionaries in media coverage of the Nigerian civil war', The Catholic Historical Review, Vol. 90, No. 4, 2004, pp. 697-718.

${ }^{4}$ See Anna Bocking-Welch, 'Imperial legacies and internationalist discourses: British involvement in the United Nations Freedom from Hunger Campaign, 1960-70', Journal of Imperial and Commonwealth History, Vol. 40, No. 5, 2012, pp. 879-896; and Kevin O'Sullivan, “Ah, Ireland, the caring nation”: Foreign aid and Irish state identity in the long 1970s', Irish Historical Studies, Vol. 38, No. 151, 2013, pp. 476-491.
} 
'Something has been happening to "charities" in the last few years', Christian Aid Director Alan Booth told his organization's supporters in autumn 1970, 'and it is nearly all good'. 50 the traditional model of giving - 'to encourage the maximum generosity to dependents' - was added a greater emphasis on development, justice, and the potential for far-reaching economic reform. ${ }^{6}$ But the change that Booth described was not driven solely by some belated 'discovery' of development by NGOs. The sector's massive expansion in the late 1960s and early 1970s owed much to its growing visibility and its standing as the primary mediator between the West and the Third World.

Biafra played a key role in that process. The logistics of the relief operation placed NGOs to the forefront of aid-giving. Their involvement grew slowly. The first International Committee of the Red Cross (ICRC) supplies arrived in Biafra in November 1967, and five months later that organization became the key co-ordinator of the relief effort in Federal-held territories. By then cases of kwashiorkor and marasmus - debilitating conditions caused by serious protein deficiency - had become increasingly prevalent, particularly among Biafran children. NGOs began to sit up and take notice. In Britain Christian Aid contributed to the World Council of Churches (WCC) relief effort, Oxfam and War on Want expanded their funding to the region, and the Save the Children Fund (SCF) sent emergency resources to one of its local administrators, John Birch, who had just undertaken a tour of the former rebelcontrolled areas in the east. Birch's description was typical of the stories beginning to filter out from Nigeria: 'As I passed through one village the mothers cried for help for their emaciated children, but I had to drive on, unable to offer relief because I had not enough manpower or supplies'?

While the conflict settled into a slow war of attrition, the escalating humanitarian crisis took centre stage. For the Federal government and the Biafran authorities hunger became a tool of propaganda and an important weapon of war - exemplified by their lengthy (and ultimately fruitless) wrangling over the possibility of a land corridor for relief. Frustrated by their inability to access Biafra on the ground, the ICRC took to the air. NGOs soon followed. Joint Church Aid - a co-operative effort of the Protestant and Catholic churches - organized night-time airlifts into Biafra from the Portuguese island of São Tomé in an effort to avoid the attentions of the Nigerian Air Force. Huge volumes of medicines, food and other goods arrived at Uli airstrip, from where they were distributed through an already-existing and complex web of feeding stations and medical centres run by Christian missionaries. With increased media attention came a greater role for NGOs and with it greater volumes of relief. By December 1969, with the eyes of the world firmly on West Africa, 250 metric tons of supplies were landed at Uli every night. ${ }^{8}$

It took time, however, for popular attention to focus on the crisis. In Britain that occurred only after 12 June 1968, when a film broadcast on ITV and a press campaign led by the Sun newspaper sparked the humanitarian response into life. By the end of the following month SCF and Oxfam relief teams had transferred to Nigeria to work under the aegis of the ICRC, and were joined by consignments of food, money and medicines delivered to West Africa. Their work testified to the expanded operational capacities of British NGOs (not least

\footnotetext{
${ }^{5}$ Christian Aid, Another year of Christian Aid: October 1969 to September 1970 (n.p., n.d. [1970?]), p. 3: School of Oriental and African Studies, University of London, Special Collections, Christian Aid Papers (hereafter CAP), CA/J/1.

${ }^{6}$ Christian Aid, Another year of Christian Aid: October 1969 to September 1970 (n.p., n.d. [1970?]), p. 3: CAP $\mathrm{CA} / \mathrm{J} / 1$.

7 'Nigeria Biafra: SCF aid', The World's Children, autumn 1968: The Save the Children Fund archive, Cadbury Research Library, University of Birmingham (hereafter SCA), Box A676.

${ }^{8}$ Aengus Finucane, 'The changing roles of voluntary organisations', in Kevin M. Cahill (ed.), A framework for survival: health, human rights and humanitarian assistance in conflict and disasters (London: Routledge, 1999), p. 180.
} 
Oxfam, whose relief team was the first such group to be sent overseas by the organization). The depth of Biafra's impact over the following eighteen months is best appreciated however by examining a subject close to the sector's heart: money. At its most basic level, the public response to the crisis resulted in a massive increase in income across the NGO community. ${ }^{9}$ In late 1968, for example, the Nigerian War Victims Appeal, run by the Disasters Emergency Committee (DEC; a campaign co-ordinating group consisting of the British Red Cross, Christian Aid, Oxfam, SCF and War on Want), raised more than GB£100,000 in less than four weeks. ${ }^{10}$ DEC's five member organizations had already jointly subscribed GB£725,000 to the ICRC's relief efforts, and would continue their high levels of spending (with some help from the British government) until the end of the war. ${ }^{11}$

In Ireland the response followed a similar trajectory: from a slow beginning, the increased media attention that began in early summer 1968 led to an explosion of NGO activity thereafter. The difference lay in the almost total absence of an Irish NGO sector prior to that period. The UN Food and Agriculture Organization's Freedom from Hunger Campaign spawned Gorta (formed in 1965), yet that organization's emphasis on long-term agricultural development had limited purchase on the popular mind-set. What Biafra's potent mix of strong missionary connections and the impact of television and print media created, therefore, was something entirely new in an Irish context. In March 1968 a meeting in Dublin of missionaries, volunteers, and other interested individuals led to the foundation of Africa Concern, the country's first indigenous humanitarian NGO. ${ }^{12}$ It was not until three months later however, when images from Biafra began to filter through to the Irish media, that the crisis grabbed the attention of the wider public. The Joint Biafra Famine Appeal (JBFA; coorganized by Africa Concern), launched in Dublin on 28 June 1968, capitalized on the large numbers of Irish priests, nuns and brothers involved in the distribution of relief to generate a massive public response. Within two months the appeal had collected IR£148,819, and in the course of the war Africa Concern alone raised more than IR $£ 1$ million. ${ }^{13}$ In effect, the crisis re-shaped Ireland's relationship with the Third World. Where once it had been defined through school-, church- and hospital-building campaigns run by missionaries, the rise of Africa Concern placed NGOs to the forefront.

What were the consequences of this rapid expansion of humanitarian action? It is an often-repeated trope that the crisis was 'the first humanitarian disaster to be seen by millions of people'. ${ }^{14}$ But that should not distract from the depth of its impact. For many it represented a first real engagement with the postcolonial world and the realities of humanitarian crisis on a massive scale. Where the public's gaze turned, opportunities proliferated for NGOs. Led by the ICRC and the JCA umbrella, new organizations emerged and others flourished with the attention and - most importantly - the funding afforded to them through massively increased public donations. They ranged from missionary societies and those directly linked to the institutional churches (Christian Aid), to religious-inspired, yet ostensibly secular organizations (Africa Concern). They included agencies formed within, and that remained closely influenced by, the imperial context (SCF), those that were part of a new generation of

\footnotetext{
${ }^{9}$ See the chart, 'Cumulated income of international aid and development NGOs, 1945-2009', in Matthew Hilton, Nick Crowson, Jean-François Mouhot and James McKay, A historical guide to NGOs in Britain: charities, civil society and the voluntary sector since 1945 (Basingstoke: Palgrave Macmillan, 2012), p. 301.

10 'Notes of the forty-fourth meeting of the Disasters Emergency Committee held on Thursday, 5th December, 1968, at 2.30 p.m., at 14, Grosvenor Crescent, London, S.W.1.': CAP CA2/F/1/9.

${ }^{11}$ Figure from 'Nigeria war relief gets $£ 100,000$ ', Guardian, 9 December 1968.

12 The organization shorted its name to 'Concern' following its intervention in East Pakistan in 1971.

${ }^{13}$ Figures from Africa Concern, First annual report of the Joint Biafra Famine Appeal for the year ending 30th June 1969 (n.p., n.d. [1969?]), p. 18; and Tony Farmar, Believing in action: Concern the first thirty years, 196898 (Dublin: A\&A Farmar, 2002), p. 24.

${ }^{14}$ Tony Vaux, The selfish altruist: relief work in famine and war (London: Earthscan, 2001), p. 15.
} 
'secularising' and 'professionalising' NGOs (Oxfam and Africa Concern), and those created as a result of international, UN-led initiatives (Gorta). They were operational and nonoperational: SCF, the missionary societies, and, to a lesser extent, Oxfam and Concern, all sent volunteers into the field; Christian Aid worked through local Church groups. Those organizations were also rivals - in Britain more so than in Ireland, where Africa Concern's only real competitor was the local Red Cross Society_-fighting over a limited pool of funding and public support. What united them, however, was the commitment to 'saving' and their success in persuading the people of Britain and Ireland that they were the ones to do it.

By 1970 names such as Christian Aid, Oxfam, Save the Children, War on Want (Britain), Africa Concern, Gorta (Ireland), Nordchurchaid (Scandinavia), Mensen in Nood (Netherlands), Misereor, Brot für die Welt (West Germany), and Caritas Internationalis (the official relief agency of the Catholic Church) were familiar in public discourse in a way that NGOs had rarely been before. Biafra gave them the opportunity to take centre stage. In the years that followed that role was consolidated. In 1971 the European non-governmental sector took a further turn when frustration at the perceived shortcomings of the ICRC operations in Biafra and East Pakistan prompted a group of French doctors to form a new organization and a new way of approaching non-governmental aid: Médecins sans Frontières. ${ }^{15}$ Those two crises, and later NGO campaigns in Africa, Asia and Latin America, created the momentum, the opportunities and the conditions for the continued expansion of the humanitarian sector. Within that context a simple but powerful equation emerged: for many in the watching public, the image that those interventions projected - of crisis, followed by NGO response-became the norm.

\section{Decolonization and NGO attitudes to Biafra}

The significance of that shift should not be under-estimated. As NGOs moved to centre stage in translating humanitarian concern into humanitarian action, they took on an equally important role in mediating between the lives of donors and life 'on the ground' in the Third World. Their advertisements, images and stories dominated the public narrative. In some cases, they did so in quite a direct fashion-Africa Concern, for example, established its own telex service to send up-to-date reports to the major Irish media outlets straight from West Africa, and in so doing had a considerable influence on the news agenda. Their impact was anything but benign. Rather, the understanding that 'representations do not simply re-present facts but also constitute them' behoves us to look more deeply at the manner in which NGOs presented Biafra to the watching public, the context in which those images were constituted, and what kind of reading of the Third World resulted. ${ }^{16}$

The dominant paradigm within which the response to Biafra was generated and articulated was that of empire - or, to be more specific, the process of adjusting European

\footnotetext{
${ }^{15}$ On the origins of Médecins sans Frontières, see Marie-Luce Desgrandchamps, 'Revenir sur le mythe fondateur de Médecins sans Frontières: les relations entre les médecins français et le CICR pendant la guerre du Biafra (1967-70)', Relations Internationales, No. 146, 2011, pp. 95-108. For more on the organization, see Eleanor Davey, 'Famine, aid and ideology: the political activism of Médecins sans Frontières in the 1980s', French Historical Studies, Vol. 34, No. 3, 2011, pp. 529-558; Joelle Tanguy, 'The Médecins Sans Frontières experience', in Kevin M. Cahill (ed.), A framework for survival: health, human rights and humanitarian assistance in conflict and disasters (London: Routledge, 1999), pp. 226-244; and Anne Vallaeys, Médecins sans Frontières: la biographie (Paris: Fayard, 2004).

${ }^{16}$ Nandita Dogra, Representations of world poverty: aid, development and international NGOs (London: I. B. Tauris, 2012), p. 1. See also Jonathan Benthall, Disasters, relief and the media (London: Sean Kingston Publishing, 2010); Peter Shiras, 'Big problems, small print: a guide to the complexity of humanitarian emergencies and the media', in Robert I. Rotberg and Thomas G. Weiss (eds), From massacres to genocide: the media, public policy and humanitarian crises (Cambridge, MA: World Peace Foundation, 1996), pp. 93-114; and Susan Sontag, Regarding the pain of others (London: Penguin, 2003).
} 
identities to fit a decolonized world. In Britain humanitarianism became a vessel through which society could construct a new sense of national purpose; it amounted, in essence, to a benign re-imagining of imperial compassion for a postcolonial world. ${ }^{17}$ When the Biafran crisis erupted, it offered an opportunity to renew this emphasis on the country's responsibilities: 'The British, with their long contacts and many nationals in Nigeria, are best able to offer this help' ${ }^{18}$ And it underlined the state's 'obligation to try to alleviate the situation'. ${ }^{19}$ There were also direct continuities from the imperial to NGO worlds. Far from abandoned, the colonial service impulse was often simply re-packaged to suit a shifting political context. Among the SCF team members with colonial experience, for example, was A. R. Y. Irvine Neave, the organization's crisis-time administrator at Ilesha, a former Lieutenant Commander in the Nigerian Navy, and a strong believer that 'superstition and ignorance' hindered SCF's efforts to aid local communities. ${ }^{20}$ That spirit of service was not limited to SCF alone. When the organization appealed in June 1968 for doctors and nurses for its medical teams who were 'interested in doing a humanitarian service of the highest order and who are prepared to rough it in a hot tropical climate for a period of four to six months' it tapped into a growing international volunteer movement exemplified by Voluntary Service Overseas - an agency founded ten years earlier by Alec Dickson, a former colonial official in Nigeria, who sought out a new role for young British men and women at the end of empire. $^{21}$

On the surface, the Irish response to Biafra was built on something very different to the British: a shared religion (Catholicism), a common colonial experience, and a narrative of humanitarian disaster. At the launch of the JBFA in June 1968, one speaker reminded the assembled that Ireland and Nigeria were united in their knowledge of 'the horror of famine and civil war'. ${ }^{22}$ The strength of the missionary connection - at the outset of the crisis there were 1,449 Irish Catholic missionaries in Nigeria, almost half of them in Biafra, and several more from the Protestant faiths - served to further underline the links between the two peoples. $^{23}$ The Igbo were described as 'very industrious people' who 'learned the value of education early on' - as the Irish had done in the nineteenth century. ${ }^{24}$ Their fortunes were held to bring out a natural empathy in the Irish 'towards Africa or towards people who were oppressed'. ${ }^{25}$ When allied to what one government official politely termed the missionaries' 'non-neutral activities', the basic politics of the conflict - small nation oppressed by its larger neighbour - also drew considerable Irish sympathy. ${ }^{26}$ Accusations of gunrunning and stories of heroism among priests, brothers and nuns in the face of hunger and adversity reinforced a simple but powerful equation: the Irish had a 'personalised and humanised interest ... they wished to give to Biafra relief materials which their own compatriots would distribute and

\footnotetext{
${ }^{17}$ Bocking-Welch, 'Imperial legacies and internationalist discourses'.

${ }^{18}$ Marjorie Perham, 'Nigeria's agony', Oxfam News, January-February 1968.

19 'The Cheshire plan', Economist, 22 November 1969.

${ }^{20}$ A. R. Y. Irvine Neave, 'Report from Nigeria (Ilesha)', September 1969: SCA Box A164.

${ }^{21}$ SCF press release, 'Appeal for Nigerian child war victims', 25 June 1968: SCA Box A164. For a (slightly hagiographical) introduction to VSO, see Michael Adams, Voluntary Service Overseas: the story of the first ten years (London: Faber and Faber, 1968).

22 Donal Nevin (Irish Congress of Trade Unions), quoted in 'Bishops plead for aid for Biafra', Irish Times, 29 June 1968.

23 'Missionary Service Centre, Irish Missionary Personnel in Developing Countries: Statistical Analysis March 1968', supplement to Catholic Missions, April 1968.

${ }^{24}$ Interview with Aengus Finucane, Dublin, 27 February 2007.

${ }^{25}$ Interview with Tony Byrne, Dublin, 21 February 2007.

${ }^{26}$ Hand-written note by [Brendan?] Gallagher, Department of External Affairs, appended to Eamon Ó Tuathail to Gallagher, 19 December 1967: National Archives of Ireland, Department of Foreign Affairs Files (hereafter NAI DFA), 2000/14/19.
} 
which they had chosen; they wished to see these materials delivered by Irish efforts and received as Irish gifts'. ${ }^{27}$

Yet the dominance of the decolonization paradigm suggests that the experiences of British and Irish NGOs were much closer than they might at first appear. From different starting points, and with differing goals, NGOs in both states assumed the mantle of organized reactions and re-imaginings of their countries' roles for the postcolonial era. Where the British public used humanitarianism to negotiate the shift from formal empire to responsible power, the changing role of Irish Catholic missionaries reflected the need to rearticulate the Irish 'spiritual empire' for this new world. From the late 1950s onwards recognition of the need to adapt to African independence led the institutional churches to reposition themselves and to emphasize what one expatriate Catholic bishop termed 'stability, co-operation and progress'. ${ }^{28}$ The deliberate talking up of church involvement in the mechanics of state building - in education and health provision in particular, but also in any activities that could be described under the broader umbrella of 'aid' —was an important part of that process. By the time Pope Paul VI published Populorum Progressio, his 1967 encyclical on 'human progress', individuals like Aengus Finucane (Holy Ghost missionary and later CEO of Concern) and Tony Byrne (also a member of the Holy Ghost Order and later head of the Cartias Internationalis airlift from São Tomé) were undertaking university courses in development studies and moving ever more strongly into the practical world of humanitarian assistance.

Africa Concern's emergence did even more to bring together the worlds of NGO humanitarianism and the missionary tradition: in practical terms, through the strong formative influence of Viatores Christi (a lay Catholic volunteer organization) and the Holy Ghost Order on its activities, but also in the tactics that it used. The organization's advertisements, carrying images of marasmus- and kwashiorkor-afflicted children and slogans like 'Is one meal a day too much to ask?', were instantly recognizable to generations of Irish people brought up on 'penny for a black baby' fund-raising campaigns in their churches, schools and local communities. And, almost eight years after Nigerian independence had prompted an outpouring of interest in the West African state, they renewed a debate that was as hierarchical as anything established by British NGOs. In 1960 the Society of African Missions (an Irish Catholic order based mainly in the Northern Region of Nigeria) had proclaimed that ' $[n]$ o country in the world owes so much to Ireland alone'. ${ }^{29}$ By June 1968 that belief had been translated into a determination to 'save Ireland's spiritual children from extermination'. ${ }^{30}$

\section{Neo-humanitarianism and the paternalism of aid}

Decolonization, therefore, imposed its own logic on the NGO sectors in Britain and Ireland. The inherently reactionary nature of that process meant that the language and practice of humanitarianism was less removed from the imperial world than its rhetoric of 'common humanity' suggested. It fitted easily into a trend that was visible across the Western NGO sector. Biafra came at the height of what Michael Barnett termed the era of neohumanitarianism, the period between the end of the Second World War and the end of the Cold War, during which new forms of global governance replaced the 'civilising' narrative of imperial humanitarianism. British and Irish NGOs were far from immune to its central

\footnotetext{
27 John A. Daly and Anthony G. Saville, The history of Joint Church Aid: volume III, unpublished manuscript (1971), p. 856: Holy Ghost Provincialite Archives, Dublin, Biafra Papers (hereafter HGBP).

${ }^{28}$ Joseph Whelan, 'Nigerian independence', Missionary Annals, October 1960.

29 'This question of race', African Missionary, October 1960.

${ }^{30}$ Joseph Whelan, 'The Great Hunger: Biafra and Ireland', 26 June 1968: HGBP Box 1: Bishop Whelan Papers.
} 
premise: much less than a fundamental shift in attitudes, neo-humanitarianism 'altered the tone more than the workings of paternalism'. 31

What did this mean in practice? Like imperialism, this neo-humanitarianism tended to reduce the complexity of crisis to simple, easily consumable messages. 'Saving men' replaced 'civilising' or 'saving souls' in what one commentator, reflecting on Africa Concern's activities (and with no apparent irony), termed the NGO 'crusade'. ${ }^{32}$ That sense of continuity was visible in the images of Biafra employed by NGOs in both states. In Britain, Christian Aid was more than aware that '[p] eople are most likely to be moved by human faces, or human figures in dejected attitudes. Women and/or children have most appeal. ${ }^{33}$ In Ireland the pervasive media image was of the Biafran child with 'limp body and tired eyes ... [that] ... reflect the anguish of a people'. ${ }^{34}$ A July 1968 article in the Dublin-based Evening Herald newspaper was not untypical in the vivid picture it drew of rural Biafra: children 'eating everything — rats, mice, lizards, frogs, grasshoppers, but the town children are not able to eat them, and this is often the difference between life and death, because these vermin do give some protein'. 35

The reduction of the crisis to such basic imagery generated an equally simplistic response. In Ireland stories of missionary relief work (including accusations of political bias and gun-running) played an important role in generating excitement and energy around Africa Concern. So too did the campaign that launched the JBFA in June 1968 - to 'Send One Ship' (S.O.S.) of relief supplies to Nigeria. ${ }^{36}$ The humanitarian imperative flattened out the complexity of the political crisis and replaced it with adventure and a belief that 'some really desperate action is needed, completely regardless of politics and danger' ${ }^{37}$ In July 1968, for example, six lorry drivers volunteered for a three-month stint with SCF 'after seeing the distressing photographs and films of starving children'. ${ }^{38}$ The relief airlift that generated such publicity and popular support was the perfect example of this reflexive urge to help in action. What better image of NGO virtuosity than that of an 'expensive and hazardous' undertaking that would continue 'no matter what it costs in effort, money or even the safety of our workers'? ${ }^{39}$

Alongside that reductive tendency, the neo-humanitarians also inherited the late colonial desire to modernize and reform. Control was an important element of this response. Descriptions of children employed in NGO campaigning - as variously 'innocent', 'emaciated', and 'pathetic mites' - reinforced paternal relationships of a humanitarian father and a powerless recipient. ${ }^{40}$ So too did the idea of flying groups of Biafran babies to the West for treatment — criticized by some (Christian Aid) but embraced by others (Africa Concern) as part of the relief effort. The very process of administering relief further reinforced the primacy of NGOs. SCF aid workers described queues of people, their foreheads marked red to designate their need for immediate attention, "clutching their tiny bowls and pointing to

\footnotetext{
${ }^{31}$ Michael Barnett, Empire of humanity: a history of humanitarianism (Ithaca, NY: Cornell University Press, 2011), p. 31.

32 'In this issue', Missionary Annals, February 1970.

33 'Briefing document to South-Warden Ltd: new advertising campaign', undated [1968?]: CAP CA/I/15/2.

${ }^{34}$ Farrell Sheridan, 'That cover', Missionary Annals, December 1968.

35 'Rats, mice keep life in hungry', Evening Herald, 6 July 1968.

${ }^{36}$ For a description of the campaign, see Farmar, Believing in action, pp. 18-22.

${ }^{37}$ Rev. David L. Ruddall to Sir Cyril Black, 2 August 1968: CAP CA/A/6/5.

${ }^{38}$ SCF press release, 'Devon drivers volunteer for Nigeria', 29 July 1968: SCA Box A164.

${ }^{39}$ Christian Aid press release, 'Christian Aid to Baifra and Nigeria: $£ 1$ million-worth of mercy supplies from churches: Mercy airlifts continue "regardless of cost", 19 July 1968: CAP CA/I/14/6.

40 'Biafra: Send One Ship' (advertisement for the JBFA), Irish Times, 25 July 1968; 'Nigeria Biafra: SCF aid', The World's Children, autumn 1968: SCA Box A676; and Geoffrey Murray, 'Fish in the chapel', World Council of Churches: Division of Inter-Church Aid, Refugee and World Service newsletter, January 1969: CAP $\mathrm{CA} 2 / \mathrm{A} / 21 / 6$.
} 
their stomachs and then to their mouths, crying, "Master, food", ${ }^{41}$ The power they wielded to relieve starvation was 'startling, and extremely satisfying ... two feedings of protein food were sufficient to abolish the swelling of the legs and to reduce the swollen abdomens'. ${ }^{42}$

In each of these scenes it was the neo-humanitarians-NGOs and missionaries - that held the keys to 'progress' and 'native' development. Not only was humanitarianism, like colonialism, something done unto others, it also carried another familiar sub-text: that Western relief agencies were bringers of all that was 'modern' and 'advanced', and couldand should - transform Biafra in their own image. 'Experts' recruited in the West administered medical and other assistance to local populations, and in Western terms. Early in the crisis one SCF official warned that he could "not foresee any efficient service of relief [in Nigeria] until we get good expatriates that we can control' ${ }^{43}$ His colleagues at the organization's 'Mothercraft Centre', a haven for families at Ilesha in south-western Nigeria, later spoke of their attempts to 'educate' local women on how to feed their children, maximize nutritional intake, and substitute 'primitive and harmful customs' with 'health hygiene at home, insistence on preventive immunisation wherever practicable, and instilling an appreciation and understanding of the needs of the infant'. ${ }^{44}$ Reports from Oxfam's relief efforts were equally filled with 'corridors for getting in large-scale supplies of carbohydrates' and the need to 'keep the protein flowing. ${ }^{45}$ That insistence on the power of science and of trained intervention was echoed in the re-articulation of the Irish missionaries' role. The tasks of relief and welfare provision were designated to the missionaries who had trained as development workers, while others like the Medical Missionaries of Mary-a Catholic order with a specifically humanitarian remit that was prominent in the relief operations in Biafrawere given an equally important role.

That process reinforced a further inheritance of neo-humanitarianism: the desire to organize the Third World and to render its 'otherness' as something that could be understood and 'known'. Following in the tradition of Africanism (Orientalism's close cousin), NGOs in Biafra replicated the dichotomies of the 'developed' and 'under-developed' worlds: traditional versus modern; subsistent versus productive; agrarian versus urban. ${ }^{46}$ That contrast was acutely visible in the descriptions of Irish missionaries who worked at feeding and medical centres deep in 'the bush'. It was present in the near-mythical status the Irish media accorded to Uli airstrip, the stretch of road turned night-time landing spot from where the JCA supplies were distributed by missionaries to locations across Biafra. British NGOs tended to much the same response. In September 1969, for example, SCF reported from Ilesha that ' $[\mathrm{m}]$ ost of the mothers who are admitted to the Centre with their children are illiterates, and it takes quite some time before they could understand the simple rules of hygiene. One cannot blame them because many of them come from the remote villages where people still live in a primitive way'. ${ }^{47}$

But the desire to re-build Biafra and Nigeria in the West's image did not end with the rebels' collapse. As early as April 1969, one SCF official argued that 'it will not be sufficient

\footnotetext{
41 'Nigeria Biafra: SCF aid', The World's Children, autumn 1968: SCA Box A676.

${ }^{42}$ N. H. Moynihan (SCF), 'Relief pathfinders in Nigeria/Biafra', The World's Children, winter 1968: SCA Box A676.

${ }^{43}$ John Birch, SCF administrator at Ilesha, to E. M. Watson, SCF overseas personnel officer, 24 April 1968: SCA Box A164.

${ }^{44}$ Lt.-Cmdr. A. R. Y. Irvine Neave (SCF administrator, Ilesha), 'Report from Nigeria (Ilesha)': SCA Box A164.

45 'Common wealth?', Oxfam News, December 1968; 'Oxfam beats malnutrition on the battle line', Guardian, 19 March 1969.

${ }^{46}$ See Valentin-Yves Mudimbe, The invention of Africa: gnosis, philosophy, and the order of knowledge (London: James Currey, 1988).

${ }^{47}$ Remi Agunlejika, 'Mothercraft Centre', undated report appended to 'Quarterly report, July-September, 1969: Ilesha': SCA Box A164.
} 
to restore conditions in Eastern Nigeria to the prewar level, the limelight of Western interested nations will demand a higher standard than the people have known in the past' ${ }^{48}$ What began as a response to disaster translated itself into a longer-term commitment to humanitarian reform. Three months after the war ended in January 1970, Oxfam reminded its supporters of the difficulties associated with rapid social and economic change in a context like that unfolding in Nigeria: 'The very world itself confounds them as they are sucked by the slipstream of modern technology from their ancient ways. They need both steadying influence and a helpful bridge to cross this chasm successfully'. ${ }^{49}$ This was not simply a story of re-building, therefore-it was also about the inability of NGOs to let go. Africa Concern's covert activities in the former Biafran territory, for example, continued long after the organization's expulsion in the aftermath of the war, driven by an inherent belief in the superiority of outside action and a concurrent belief that the locals charged with action (in this case the Nigerian National Committee for Rehabilitation and the Nigerian Red Cross) could not, or would not, deal properly with the residual crisis.

\section{Biafra, NGOs and Western internationalism}

The evidence presented here - of the power of decolonization in shaping the attitudes and activities of humanitarian NGOs - reveals strong parallels between the British and Irish experience of the Biafran crisis. But how do we unpack that 'different-but-similar' narrative to describe the emergent model of NGO humanitarianism and what it meant for Western conceptions of the Third World? Why, for example, did pride in Ireland's anticolonial past and the constant references to a shared experience of famine produce a humanitarian response that looked remarkably similar to a British society still coming to terms with the legacy of direct imperial control? It is plainly reductivist to see NGOs simply as continuations, as Manji and O'Coill put it, of 'the work of their precursors, the missionaries and voluntary organizations that cooperated in Europe's colonization and control of Africa' ${ }^{50}$ Their roleboth in Africa and in Britain and Ireland - was much more complex than that formulation allows. Yet the extent to which NGOs in both countries fell easily into the neo-humanitarian narrative does point to a model of humanitarianism rooted in a set of shared social and ideological norms.

One way of understanding this convergence is to think of it in terms of the dual logic of 'difference' and 'oneness' that dominates the imagery utilized by Western NGOs. ${ }^{51}$ In that reading, the humanity that drives compassion is counterbalanced by a clear hierarchy of difference and distance between North and South. In Biafra the concept of a shared 'humanity' was prominent in British and Irish calls to humanitarian action. Oxfam's spring 1969 statement on the crisis warned that 'apart from the historical associations, humanity demands that Britain faces this awful dilemma'. ${ }^{52}$ Influenced by its roots in the lay Catholic volunteering agency Viatores Christi and its links to the Holy Ghost Fathers, Africa Concern viewed its role in similar terms to religious organizations like Christian Aid (the official aid agency of the Protestant British Council of Churches) and the Catholic missionary organizations that were so prominent in the distribution of relief: 'part of a world-wide movement of the Spirit which has united men of goodwill of every denomination as never

\footnotetext{
${ }^{48}$ Lt-Col. J. V. Hawkins, director, overseas relief and welfare, SCF, 'The Save the Children Fund: Report on visit to Nigeria, 9th to 19th April, 1969', 25 April 1969: SCA Box A164.

49 'A bridge of donors', Oxfam News, April 1970.

${ }^{50}$ Firoze Manji and Carl O’Coill, 'The missionary position: NGOs and development in Africa', International Affairs, Vol. 78, No. 3, 2002, p. 568.

${ }^{51}$ Dogra, Representations, p. 3.

52 'Nigeria/Biafra war: a statement', Oxfam News, May 1969.
} 
before in efforts to lessen human misery'. ${ }^{53}$ The NGO-sustained description of Biafra tended to something different however - an image of 'helplessness' and the 'desperate' plight of the Igbo people that reinforced hierarchies of humanity and emphasized the distance between the two worlds. Biafra's role as the first televised famine was marked by an over-exposure to images of crisis that frequently tended to numb rather than inspire the public. The 'long distance viewer', as one Guardian journalist termed them, 'switched off because they'd seen it before and it hurt them'. 54 That admission was important: while the crisis brought suffering into Western living rooms and loosened humanitarian compassion, it remained something 'out there', something that could be turned down or off, and something that remained largely extraneous to everyday existence.

Reading the donor-NGO-recipient chain in terms of this 'radically unequal order that is the mark of the humanitarian relationship' suggests that we need to think about the organized response to Biafra not just in terms of empire and the order imposed by decolonization, but also as part of a model of liberal governance and the spread of Western values through the medium of the NGO. ${ }^{55}$ The depoliticization of relief was an important first step in that process. From the beginning of the Biafran crisis British and Irish NGOs attempted to elevate their actions above and outside of the politics of the conflict. Christian Aid stated its desire to be 'impartial in regard to the military and political issues of the warand [to] try to relieve suffering on both sides, as equally as possible'. ${ }^{56}$ It was not alone. Oxfam told readers of its newsletter in December 1968 that it was 'in no way concerned with the politics of the situation ... In pleading for a cease-fire our only concern is for humanity. ${ }^{57}$

Even in Ireland, where the crisis was experienced in a broadly pro-Biafran contextto the extent that Africa Concern and the Holy Ghost Fathers were among the first organizations to be expelled from Nigeria after Biafra's collapse - this depoliticization of the narrative was openly evident. In popular discourse humanitarianism was designated to the realm of Christian humanity and viewed as something quite apart from the exigencies of civil war, including any references to genocide made by the rebels' supporters. The analogy of industrial action employed by journalist Raymond Smith to justify Catholic involvement in the relief effort was typical: 'if a strike brings men out on the street and if that strike is prolonged with the result that their families are faced with hunger, the relief agencies do not stop to consider whether the strike is justified or not. They see defenceless women and children suffering - and come to their immediate help. It should be left to others to debate the issues in the strike' ${ }^{58}$ Solidarity in this case stood above politics and instead brought a broadly shared pride in the role played by the Irish missionary community—and, by extension, Africa Concern - that did little to interrogate the nuances of Christian humanitarian action.

Depoliticization of the relief effort had the same result as the imagery employed by the NGOs, flattening out the complexity of Biafran and Nigerian society in favour of the moral imperative of humanitarian aid. While SCF, Christian Aid, Oxfam and War on Want remained closely conversant with British officials, operated under the ICRC umbrella and were frequently at the mercy of changing Federal and Biafran priorities - where and when

\footnotetext{
${ }^{53}$ Vincent Grogan and John O’Loughlin Kennedy, 'Ireland's response: another year of giving and sharing', in Africa Concern, Africa Concern (n.p., n.d. [1969?]), p. 5.

${ }^{54}$ Nancy Banks-Smith, 'Television: World in Action', Guardian, 30 Dec. 1969.

${ }^{55}$ Didier Fassin, Humanitarian reason: a moral history of the present (Berkeley, CA: University of California Press, 2012), p. 253.

${ }^{56}$ Rev. Alan Brash (Director, Christian Aid) to all Christian Aid staff, 9 December 1969: CAP CA2/A/2/21/6. For an overview of the issue, see Brash, 'Confidential Paper for Projects Sub-Committee: The political implications of Christian Aid's projects', September 1969: CAP CA2/D/3/4.

57 'Common wealth?', Oxfam News, December 1968.

${ }^{58}$ Raymond Smith, 'Nigeria', Missionary Annals, April 1970.
} 
they could send food, how it was distributed, how many expatriate personnel could be employed, and in what locations - these developments were little discussed in public. Rather they remained buried beneath the primacy of impartiality and the immediate response to hunger: 'the most heartbreaking consequence of this war'. ${ }^{59}$ Equally absent was any sustained public critique of imperial and missionary continuities as the building blocks of humanitarian action. In their place came NGOs - the embodiment for many of the inherent 'good' that was 'people-to-people' action.

Taking that analysis a step further, the role of British and Irish NGOs in Biafra was also crucial in the acceleration of what Mark Duffield termed 'permanent emergency': the reproduction of the humanitarian movement through consistent crisis, by simultaneously emphasising NGO neutrality and stripping away any complexity from the recipients of disaster relief. ${ }^{60}$ The primacy of 'emergency' and 'relief' in West Africa reinforced the image of NGOs as above politics, while further negating the agency of those to be 'saved'. The complete eclipse of Gorta's model of long-term development in Ireland by the immediacy of Africa Concern's activities provided a good example of this hierarchy in practice. In 1969 Gorta formed a 'Nigeria/Biafra advisory group', made up of representatives of missionary organizations, its own council members and government officials, yet dismissed the package of projects it put forward as 'not a very dramatic one'. ${ }^{61}$ They had reason to be concerned. By July of that year the organization's regional officers reported 'a great deal of surprise and dismay among the public that Gorta should be concentrating itself with long-term objectives while people were actually dying of starvation' ${ }^{62}$

Therein lay Biafra's most telling contribution to the popular understanding of the Third World: the primacy of emergency and the immediate NGO response. What Gorta experienced in West Africa was merely underlined in a succession of crises that followed. The flight of refugees from civil war in East Pakistan in 1971 inspired not an interrogation of its causes but a Concern-run 'Pakistan Famine Appeal'. In Cambodia eight years later NGOs focussed attention away from the politics of Vietnamese intervention and the residual influence of the Khmer Rouge regime towards a situation that Oxfam technical officer Jim Howard described as 'worse than Biafra. But you can't make comparisons like that when there are so many people dying of starvation. ${ }^{63}$ In Ethiopia (1984-85) the situation was much the same. British and Irish NGOs preferred to emphasize the distribution of aid than to publicly criticise the policies of displacement and re-settlement followed by the Derg regime. The lesson was simple: the importance of the decolonization paradigm was reduced, but the power of neo-humanitarianism and Western liberal governance remained.

\section{Conclusion}

This article has traced the evolution of the Biafran 'humanitarian encounter' in terms of new beginnings (for the NGO sector), of the decolonization paradigm (the rise of neohumanitarianism), of paternalism (aid as something done unto others), and of Western internationalism and the rise of the liberal humanitarian regime. In Biafra, or at least in the NGO response to Biafra, those elements collided so that the 'NGO moment' helped to

\footnotetext{
59 'The Cheshire plan', Economist, 22 November 1969.

${ }^{60}$ See Mark Duffield, Development, security and unending war: governing the world of peoples (Cambridge: Polity Press, 2007).

${ }^{61}$ Martin O’Doherty, Dept. of Agriculture and Fisheries, to Eamon Ó Tuathail, Department of External Affairs, 4 June 1969: NAI DFA 2005/145/1608.

${ }^{62}$ Neil Blaney, Minister for Agriculture and Fisheries, to Frank Aiken, Minister for External Affairs, 29 July 1969. Note that the Irish government retained a prominent role in Gorta's activities until the late 1980s: NAI DFA 2005/145/1608.

${ }^{63}$ Quoted in Nick Davies, 'Oxfam to send aid to Cambodia', Guardian, 12 September 1979.
} 
crystallize a particular humanitarian vision of, and relationship with, the Third World that did little to challenge, and much to reinforce, that cultivated in the colonial era.

In constructing the 'imaginative geographies' of British and Irish attitudes to the Third World - the "practice of designating in one's mind a familiar space which is "ours" and an unfamiliar space beyond "ours" which is "theirs" - the NGO response to Biafra largely stripped away the complexity and agency of the very society that it purported to help. ${ }^{64}$ Decolonization and the shift to neo-humanitarianism were central to that narrative. In Britain, the relief effort amounted to a re-packaging of imperial responsibilities and care for far-off communities for a postcolonial era. In Ireland the response-whether articulated through Africa Concern or the missionary relief effort - was closely associated with the country's 'religious empire'. In both states popular representations of the crisis reinforced a tendency to view the peoples of the Third World as inferior or, at the very least, as near-perpetual victims. The inherent paternalism and power imbalances that the NGO 'crusade' made integral to public discourse further emphasized this popular imagining of the Third World. Biafra became a place to be 'saved' by 'experts' and by the superiority of scientific knowledge: of nutrition, technology and medicine.

To argue that this was the case is not to impose some kind of neat divide between 'good' and 'bad' humanitarianism or between 'the West' and 'the rest'. We should not be too quick to dismiss the positive virtues embodied by NGOs, missionaries and volunteers, for example. Nor were NGOs universally comfortable with a Biafra-inspired model of the developing world. In May 1969 Christian Aid Director Alan Brash wrote to the organization's public relations officer to describe his frustration at the image of Africa generated by the on-going crisis. His comments said much about the dominant public vision of the Third World: 'We do not want any more films which result simply in provoking a relief programme. A film including some of the war damage but leading on to an interpretation of the rehabilitation situation, not only the need but also the potential, would be meaningful'. ${ }^{65}$

The Biafra-inspired 'imaginative geography' of the Third World should instead lead us to realize that humanitarianism could be simultaneously (and paradoxically) outwardly all encompassing in its ideals yet rooted in Western social and ideological norms, and to appreciate the important role that NGOs played in making it so. In their broadest sense, NGOs have been feted as central building blocks in an increasingly interdependent post-1945 world. ${ }^{66}$ They created new frames of reference for Western publics in terms of regional, transnational and global foci rather than simply local or national ones. And for their supporters they became interlocutors between worlds. In translating and transmitting Biafra's plight, NGOs like Oxfam and Africa Concern articulated what Didier Fassin described as the core of humanitarian reason: 'the response made by our societies to what is intolerable about the state of the contemporary world' ${ }^{67}$ It was a keenly felt set of values.

Yet the NGO experience of Biafra warns us that we should not naively assume that this 'people-to-people' action implied the existence of a utopian 'common humanity' based on justice, equality and some commonly held notion of human rights. Alan Brash's misgivings about the use of disaster imagery did not result in its abandonment by the sector.

\footnotetext{
${ }^{64}$ Edward Said, Orientalism (London: Penguin, 2003), p. 54.

${ }^{65}$ Alan Brash to Hugh Samson, 2 May 1969: CAP CA/I/15/6.

${ }^{66}$ See, for example, Akira Iriye, Global community: the role of international organizations in the making of the contemporary world (London: University of California Press, 2002); Bruce Mazlish, The new global history (Abingdon: Routledge, 2006); and Andrew Arsan, Su Lin Lewis and Anne-Isabelle Richard, 'Editorial - the roots of global civil society and the interwar moment', Journal of Global History, Vol. 7, No. 2, 2012, pp. 157165.

${ }^{67}$ Fassin, Humanitarian reason, p. 252.
} 
Steeped in imperial and missionary continuities, and often paternalistic in language and practice, NGOs tended to reinforce and re-articulate rather than challenge existing stereotypes of the Third World. The belief in humanitarianism as an inherent 'good' and an attempt to tackle the problems of the Third World merely draws attention to the unconscious, but no less potent, inequalities inherent in the aid giving process. This was, after all, largely a Western projection on to the Third World. And the fact that NGOs were highly successful while pursuing it testifies to its purchase among the watching Western public. It also leads us to one final lesson that British and Irish organizations shared with the anti-apartheid movement, another prominent contemporary international humanitarian campaign. The watching public needed translators like NGOs to make sense of the outside world. Or, as Håkan Thörn rather bluntly put it, 'common humanity' was more appealing in the West when it was expressed with a local accent and 'a white face'. ${ }^{68}$

${ }^{68}$ Håkan Thörn, Anti-apartheid and the emergence of a global civil society (Basingstoke: Palgrave Macmillan, 2006), p. 74. 